\title{
LEAF CHLOROPHYLL CONTENT ESTIMATION IN THE MONARCH BUTTERFLY BIOSPHERE RESERVE
}

\author{
ESTIMACIÓN DEL CONTENIDO DE CLOROFILA EN LA RESERVA \\ DE LA BIÓSFERA MARIPOSA MONARCA
}

\author{
Ma. Luisa España Boquera*, Philippe Lobit y Vilma Castellanos Morales
}

Instituto de Investigaciones Agropecuarias y Forestales, Universidad Michoacana de San Nicolás de Hidalgo. Posta Veterinaria y Zootécnica, km 9.5 carretera Morelia-Zinapécuaro, Michoacán, México.

* Autor para correspondencia (boquera@umich.mx)

\section{SUMMARY}

Chlorophyll is an essential element of photosynthesis and its content in plant leaves indicates their photosynthetic capacity as well as the presence of stress or diseases. The purpose of this work was to evaluate the feasibility of estimating chlorophyll content in the Monarch Butterfly Biosphere Reserve forest (Sierra Chincua sanctuary, México) based on vegetation indices calculated by using hyperspectral reflectance measurements of plant leaves. This study focused on oyamel (Abies religiosa $\mathbf{L}$.) which is the main tree specie of this area. Leaf samples were taken on 140 trees and analyzed for chlorophyll $a$ and $b$, nitrogen and carbon content. The hyperspectral reflectance spectra were measured on each sample and different vegetation indices were calculated. Results showed that the indices best correlated with chlorophyll content were the red edge position index $(r=0.531)$ and the red edge position chlorophyll reflectance index $(r=0.506)$, followed by the MERIS terrestrial chlorophyll index $(r=0.497)$ and the green chlorophyll reflectance index $(r=$ 0.472). Although there was a significant correlation between nitrogen and chlorophyll content, none of the indices studied here correlated with nitrogen content. The influence of various environmental factors (altitude, slope, vegetation density and aspect) on leaf composition (nitrogen, carbon chlorophyll content and chlorophyll $a / b$ ratio) and on the vegetation indices was studied. Environmental factors had an influence on both leaf composition and vegetation indices. Chlorophyll and nitrogen content were influenced mostly by the altitude and slope of the site while vegetation indices were affected mostly by its orientation.

Index words: Abies religiosa, chlorophyll, leaf spectral response, vegetation indices.

\section{RESUMEN}

La clorofila es un componente esencial para la fotosíntesis y su contenido en las hojas de las plantas es un indicador de su capacidad fotosintética, así como de la presencia de un estrés o enfermedad. El propósito de este trabajo fue evaluar la factibilidad de estimar el contenido de clorofila en el bosque de la Reserva de la Biósfera Mariposa Monarca (santuario de Sierra Chincua, México), a partir de índices de vegetación calculados mediante medidas hiperespectrales de reflectancia de hojas. Se estudió el oyamel (Abies religiosa L.), por ser la especie arbórea más importante de la zona. A partir de los espectros de 140 muestras se calcularon diferentes índices de vegetación y se establecieron las correlaciones con los contenidos de clorofila $\mathbf{N}$ y $\mathrm{C}$. Los resultados muestran que los índices mejor correlacionados con el contenido de clorofila son: el "red edge position" $(\mathrm{r}=\mathbf{0 . 5 3 1})$ y el "red edge position chlorophyll reflectance index" $(r=0.506)$, seguidos por el MERIS "terrestrial chlorophyll index" $(r=0.497)$ y el "green chlorophyll reflectance index" $(r=$ 0.472). Si bien hubo una correlación significativa entre los contenidos de nitrógeno y clorofila, ninguno de los índices estudiados se correlacionó con el contenido de nitrógeno. Se analizó la influencia de varios factores ambientales (altitud, pendiente, densidad y orientación) sobre la composición de las hojas (contenidos de nitrógeno, carbono y clorofila y proporción entre clorofilas $a$ y $b$ ) y sobre los índices de vegetación. La composición de las hojas es principalmente afectada por la altitud y la pendiente del lugar, mientras que los índices de vegetación son principalmente afectados por la orientación.

Palabras clave: Abies religiosa, clorofila, respuesta espectral, índices de vegetación.

\section{INTRODUCTION}

Among the different variables used to evaluate the condition of an ecosystem, the content of leaf nitrogen, chlorophyll and other pigments are the most important, since they are closely related to the photosynthetic capacity and physiological status of plants.

Individual leaf is a common scale at which indicators of forest health have been developed. Foliar photosynthetic pigment concentrations (chlorophyll $a$ and $b$, carotenoids) typically decrease in response to stress or diseases. On the other hand, environmental factors are known to affect foliar structural chemistry (cellulose and lignin), as they determine growing conditions at time of leaf formation. These changes produce large differences in leaf reflectance and transmittance spectra and allow a remote sensing monitoring of plant health. Thus, remote sensing monitoring of structural constituents may allow for forest 
health monitoring of the long-term environmental conditions while the differences in foliar pigment levels would be indicative of the near-term growing environment (Campbell et al., 2004; Blackburn, 2007). At canopy scale, spectral properties are determined by a combination of factors, including foliar level pigments, canopy density and structure. All these factors must be taken into account in order to up-scale the knowledge developed at the leaf level to the scale of the entire forest, and a calibration with respect to measurements is needed (Pinkard et al., 2006; Pu et al., 2008; le Maire et al., 2008; Houborg et al., 2009).

Several vegetation indices based on measurements of the reflectance in specific wavelengths have been identified as indicators of vegetation physiological properties. The objectives of this work were to test different vegetation indices to study the relationship between leaf chlorophyll content and spectral response of the Monarch Biosphere Reserve main tree specie, Oyamel (Abies religiosa L.), and to study the influence of environmental factors (as orientation, slope and tree density) on the chlorophyll content and on the indices studied. The correlation between chlorophyll and nitrogen and carbon content was analyzed. The feasibility of calculating the studied indices from satellite images and the implications of scaling estimated chlorophyll content from leaf to canopy scale were thus discussed.

\section{MATERIALS AND METHODS}

The study was carried out in the Sierra Chincua Sanctuary, which is part of the Monarch Butterfly Reserve, in Michoacán, México. This territory presents uneven landscapes, with big differences in altitude (between 2400 and $3600 \mathrm{~m}$ ), orientation and slope (SEMARNAT, 2001). The plant species chosen for the experiment was Abies religiosa L. (commonly known as Oyamel), the most characteristic species at the study area.

The 162 sampling of leaves was carried out over three days: April 25, May 2 and May 11, 2005, and were collected according to the following procedure: a $3 \mathrm{~km} \mathrm{x}$ $3 \mathrm{~km}$ area, defined by the UTM coordinates 14Q 364E $2177 \mathrm{~N}$ and 14Q 367E 2174N; was chosen and divided into nine squares $(1 \mathrm{~km} \times 1 \mathrm{~km}$ each); within each square three elementary sample units (ESU) of approximately 20 $\mathrm{m} \times 20 \mathrm{~m}$ were selected at random positions, and within each ESU six trees were chosen. One well-exposed shoot corresponding to the previous year's growth was taken on each tree (at the time of sampling, new buds had already begun to develop in all the trees). The samples included the leaves collected on the same branch. For each sample, a bundles of at least three leaves was measured in an UVvisible spectrophotometer (Perkin Elmer, Lambda 35®, precision $1 \mathrm{~nm}$ ), equipped with an integration sphere (LabSphere $\left.{ }^{\circledR}\right)$, to obtain the reflectance spectrum in the 400 to $850 \mathrm{~nm}$ range. The measurements were repeated at three positions and the average of the three reflectance spectra was obtained. The following vegetation indices were calculated: REP, MTCI, (Chl)RIgreen, (Chl)RIREP, HNDVI, SIPI, NPCI and PRI using the averaged reflectance spectrum. The definition and calculation of each index can be found in Table 1 .

The chlorophylls $a$ and $b$ content were obtained by extraction in DMSO (di-methyl sulfoxyde), following the method of Barnes et al. (1992). After drying the samples $\left(48 \mathrm{~h}\right.$ at $\left.105{ }^{\circ} \mathrm{C}\right)$ in a heat cabinet (Mettler Toledo®, PR 8002), the nitrogen $(\mathrm{N})$ and carbon (C) content were analysed with an elemental analyzer (Carlo Erba FlashEA-1112®).

For each ESU several characteristics of its environment were recorded and classified into two levels: vegetation density (low and high), orientation interpreted as exposure to solar radiation (low - N, NE, NW - and high - S, SE, SW), slope (low $<23 \%$ and high $>23 \%$ ) and altitude (low $<3000$ and high $>3000 \mathrm{~m}$ ). Slope and orientation data were acquired from a visual interpretation of aerial photographs and very high resolution satellite data of the area available in Google Earth.

Table 1. Vegetation indices calculated from leaf spectra.

\begin{tabular}{|c|c|c|c|}
\hline Index & Description & Formula & Author \\
\hline REP & Red edge position & $\begin{array}{l}708.75+45\left(\mathrm{Rim}_{\mathrm{im}}-\mathrm{R}_{708.75}\right) /\left(\mathrm{R}_{753.75}-\mathrm{R}_{708.75}\right) \\
\mathrm{Rim}_{\mathrm{im}}=\left(\mathrm{R}_{665}-\mathrm{R}_{778.75}\right) / 2\end{array}$ & Clevers et al. (2002) \\
\hline MTCI & MERIS terrestrial chlorophyll index & 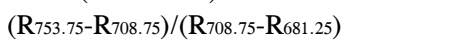 & Dash and Curran (2004) \\
\hline (Chl)RIgreen & Chlorophyll reflectance index green & $\left(\left(\mathrm{R}_{520-585}\right)^{-1}-\left(\mathrm{R}_{750-800}\right)^{-1}\right) \mathrm{R}_{750-800}$ & Gitelson and Merzlyak (2004) \\
\hline (Chl)RIREP & Chlorophyll reflectance index REP & $\left(\left(\mathrm{R}_{695-740}\right)^{-1}-\left(\mathrm{R}_{750-800}\right)^{-1}\right) \mathrm{R}_{750-800}$ & Gitelson and Merzlyak (2004) \\
\hline HNDVI & Hyperspectral normalized differential vegetation index & $\left(\mathrm{R}_{800}-\mathrm{R}_{680}\right) /\left(\mathrm{R}_{800}+\mathrm{R}_{680}\right)$ & Oppelt and Mauser (2005) \\
\hline SIPI & Structural independent pigment index & $\left(\mathrm{R}_{800}-\mathrm{R}_{445}\right) /\left(\mathrm{R}_{800}-\mathrm{R}_{680}\right)$ & Peñuelas et al. (1995a) \\
\hline NPCI & Normalized pigment chlorophyll ratio index & $\left(\mathrm{R}_{680}-\mathrm{R}_{430}\right) /\left(\mathrm{R}_{680}+\mathrm{R}_{430}\right)$ & Peñuelas et al. (1993) \\
\hline PRI & Photochemical reflectance index & $\left(\mathrm{R}_{531}-\mathrm{R}_{570}\right) /\left(\mathrm{R}_{531}+\mathrm{R}_{570}\right)$ & Peñuelas et al. (1995b) \\
\hline
\end{tabular}


The statistical analysis were performed using the $\mathrm{R}$ software ( $\mathrm{R}$ Development Core Team, 2010). Linear correlation were established between vegetation indices and chlorophyll, $\mathrm{C}$ and $\mathrm{N}$ content, and the correlation coefficient, $r$, was calculated. The effects of the environmental factors on composition and vegetation indices were studied by an analysis of variance. Quantitative factors were converted to qualitative factors by classifying them into two levels (higher or lower than the median value). The experimental unit considered was the leaf sample (equivalent to the individual tree, since one sample per tree was taken), and the design was considered to be completely randomized.

\section{RESULTS AND DISCUSSION}

The correlations between $\mathrm{C}$ and $\mathrm{N}$ content and total chlorophyll content $(a+b)$ and chlorophyll ratio $(a / b)$ are shown in Figure 1. N content presented a significant correlation $(\mathrm{P} \leq 0.001)$ with total chlorophyll content, although with low correlation coefficients $(<0.4)$. No significant correlation was found between $\mathrm{N}$ or $\mathrm{C}$ contents and chlorophylls ratio.

Figure 2 presents regressions between total chlorophyll content and vegetation indices calculated from leaf spectra. Among the indices tested (described in Table 1), HNDVI and R550 (green reflectance alone) showed the lowest correlation with chlorophyll content. REP and (Chl)RIREP indices correlated better with total chlorophyll content. MTCI, designed as an alternative to REP with a simpler formula and higher sensitivity at high chlorophyll levels (Dash and Curran, 2004), was not more convenient than the REP in this case because chlorophyll content was low.
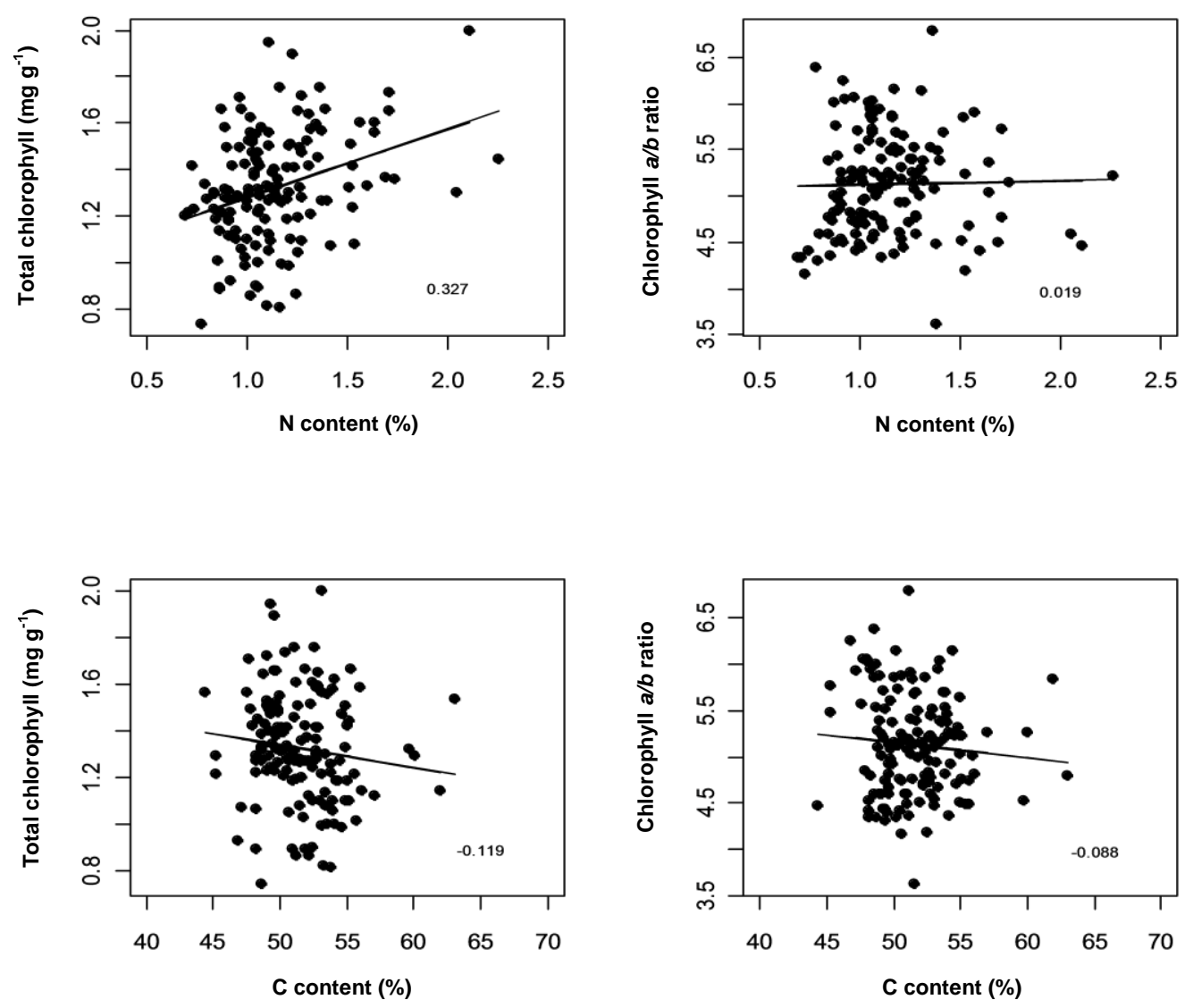

Figure 1. Linear correlation (Pearson coefficient, $r)$ between total chlorophyll content $(a+b)$ and chlorophyll ratio $(a / b)$, and nitrogen $(\mathrm{N})$ and carbon $(\mathrm{C})$ content $(\%)$. 


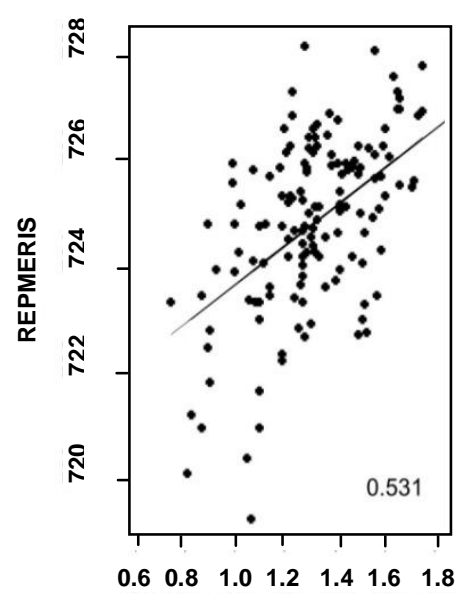

Total chlorophyll ( $\left.\mathrm{mg} \mathrm{g}^{-1}\right)$

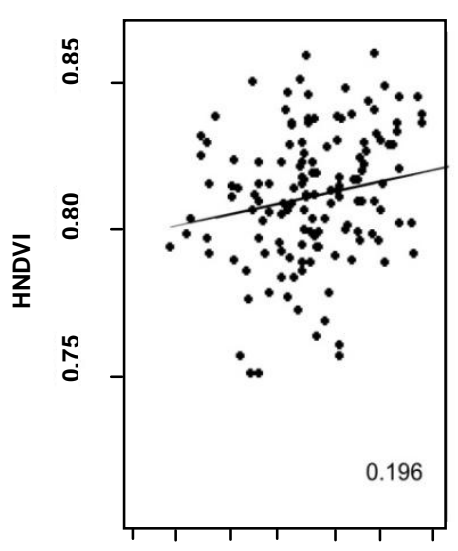

$\begin{array}{lllllll}0.6 & 0.8 & 1.0 & 1.2 & 1.4 & 1.6 & 1.8\end{array}$

Total chlorophyll $\left(\mathrm{mg} \mathrm{g}^{-1}\right)$

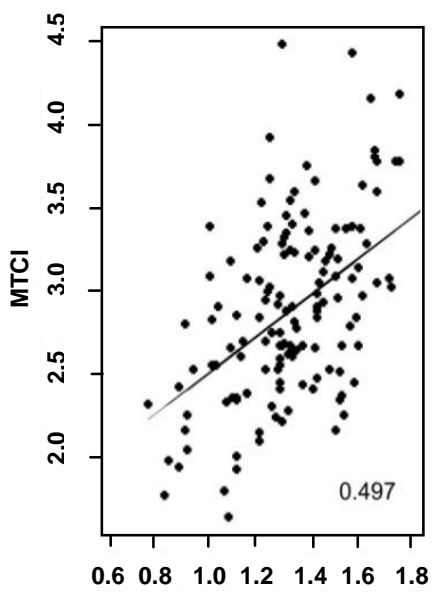

Total chlorophyll ( $\mathrm{mg} \mathrm{g}^{-1}$ )

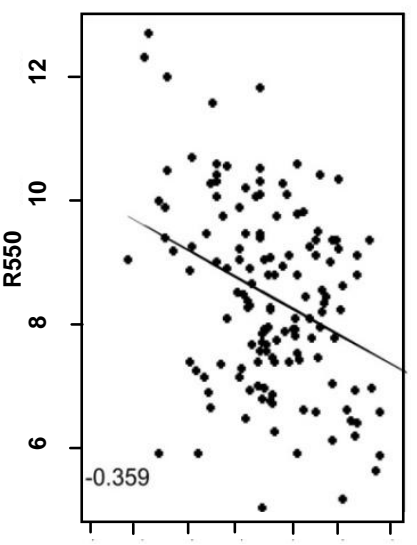

$\begin{array}{lllllll}0.6 & 0.8 & 1.0 & 1.2 & 1.4 & 1.6 & 1.8\end{array}$

Total chlorophyll $\left(\mathrm{mg} \mathrm{g}^{-1}\right)$
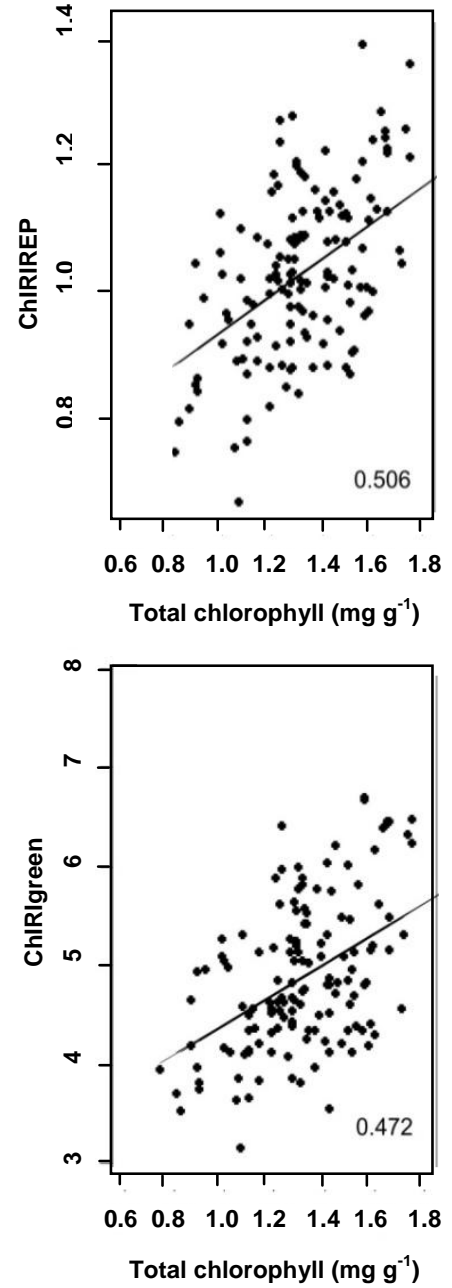

Figure 2. Linear correlation (Pearson coefficient, $r$ ) between total chlorophyll content and related vegetation indices (REP, MTCI, (Chl)RIreP, HNDVI, R550, (Chl)RIgreen).

(Chl)RIgreen and (Chl)RIREP indices designed by Gitelson and Merzlyak (2004) are roughly equivalent to R550 and REP indices respectively, but include a correction in the near infrared that presumably to accounts for differences in cell structure. Compared to $\mathrm{R}_{550}$, (Chl)R $\mathrm{R}_{g r e e n}$ index presented a better correlation with chlorophyll content. The correlations observed with the (Chl)RIREP index however were lower than for REP. In general, these results are in agreement with the findings of other authors, as the most sensitive wavelength is located in the red-edge region (le Maire et al., 2008; Steele et al., 2008).

No significant correlation between nitrogen $(\mathrm{N})$ content and any of the calculated spectral indices was found in any case $(\mathrm{P}>0.05)$. The relationship between $\mathrm{N}$ and vegetation index can be affected by species; Pinkard et al. (2006) found a weak correlation for eucalyptus (Eucaliptus globulus, L.). $\mathrm{N}$ does not affect spectral response directly, but through alterations in chlorophyll content, leaf cellular structure or plant architecture (Baret and Fourty, 1997). This is particularly true for noncultivated species where $\mathrm{N}$ availability is usually limited.

The influence of environment factors recorded in each ESU on $\mathrm{N}$ and $\mathrm{C}$ content and on chlorophyll content and chlorophyll $a / b$ ratio is presented in Table 2 . Table 3 shows the influence of environment factors on vegetation indices. Concerning the chemical composition of leaves, slope and altitude affected both $\mathrm{C}$ content $(\mathrm{P} \leq 0.001)$ and $\mathrm{N}$ content $(\mathrm{P} \leq 0.05$ and $\mathrm{P} \leq 0.1$ respectively) while the slope $\mathrm{x}$ altitude interaction affected chlorophyll content $(\mathrm{P}$ $\leq 0.001)$. Both the slope $(P \leq 0.001)$ and the density $x$ altitude interaction $(\mathrm{P} \leq 0.01)$ had a significant effect on chlorophyll $a / b$ ratio. Only $\mathrm{N}$ content was affected by orientation $(\mathrm{P} \leq 0.001)$, but the orientation $\mathrm{x}$ density interaction had a significant effect $(\mathrm{P} \leq 0.05)$ on chlorophyll content. 
Table 2. Analysis of variance of the effect of several environmental factors (al: altitude, s: slope, d: density, as: aspect) and their interactions on chlorophyll content $(a+b)$, chlorophyll ratio $(a / b)$, and nitrogen and carbon content. For each factor, only two levels were considered: low or high. Significance codes: 0 '***' $0.0011^{\prime * * 1} 0.01$ '*' 0.05 '.' 0.1 'ns'.

\begin{tabular}{|c|c|c|c|c|}
\hline & Nitrogen & Carbon & Chlorophyll content $(a+b)$ & Chlorophyll ratio $(a / b)$ \\
\hline al & . & *** & ns & ns \\
\hline $\mathrm{s}$ & $*$ & $* * *$ & ns & $* * *$ \\
\hline $\mathrm{d}$ & ns & ns & ns & ns \\
\hline as & $* * *$ & ns & ns & . \\
\hline $\mathrm{s} \times \mathrm{al}$ & . & $*$ & $* * *$ & $\mathrm{~ns}$ \\
\hline $\mathrm{s} \mathrm{x} \mathrm{d}$ & . & ns & $\mathrm{ns}$ & ns \\
\hline al $\times d$ & . & ns & ns & $* *$ \\
\hline $\mathrm{sx}$ as & ns & $*$ & . & . \\
\hline al $\mathrm{x}$ as & . & . & ns & ns \\
\hline $\mathrm{d} x$ as & $*$ & ns & $* *$ & . \\
\hline s $x$ al $x d$ & $*$ & ns & . & $*$ \\
\hline $\mathrm{S} \mathrm{x}$ al $\mathrm{x}$ as & ns & ** & $\mathrm{ns}$ & . \\
\hline
\end{tabular}

Table 3. Analysis of variance of the effect of several environmental factors (al: altitude, s: slope, d: density, as: aspect) and their interactions

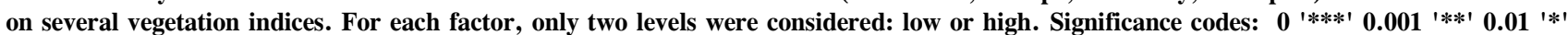
0.05 '.' 0.1 'ns'.

\begin{tabular}{|c|c|c|c|c|c|c|c|c|c|}
\hline & R550 & HNDVI & REP & MTCI & ChlRIREP & ChlRIgreen & PRI & SIPI & NPCI \\
\hline al & ns & $* *$ & ns & ns & ns & ns & . & ns & $\mathrm{ns}$ \\
\hline s & $* *$ & ns & $*$ & . & $*$ & ns & $* *$ & $*$ & . \\
\hline d & . & $* *$ & ns & ns & $*$ & $*$ & ns & ns & ns \\
\hline as & $* * *$ & $* * *$ & $* * *$ & $* * *$ & $* * *$ & $* * *$ & ns & ns & ns \\
\hline al x s & $* *$ & ns & $*$ & $*$ & $*$ & $* *$ & ns & ns & ns \\
\hline al $x d$ & ns & $\mathrm{ns}$ & $\mathrm{ns}$ & $\mathrm{ns}$ & ns & ns & $\mathrm{ns}$ & $\mathrm{ns}$ & $\mathrm{ns}$ \\
\hline al $\mathrm{x}$ as & ns & ns & ns & ns & ns & ns & ns & . & ns \\
\hline $\mathrm{s} \times \mathrm{d}$ & $\mathrm{ns}$ & $\mathrm{ns}$ & ns & ns & ns & $\mathrm{ns}$ & ns & * & $*$ \\
\hline $\mathrm{sx}$ as & ns & . & ns & ns & ns & ns & ns & ns & . \\
\hline $\mathrm{dx}$ as & $* *$ & $* *$ & $*$ & $*$ & $*$ & $* *$ & ns & ns & ns \\
\hline al x s x d & $* * *$ & $\mathrm{~ns}$ & $*$ & $* *$ & $*$ & . & ns & $\mathrm{ns}$ & ns \\
\hline al $\mathrm{x} \mathrm{s} \times$ as & ns & ns & ns & ns & ns & ns & ns & ns & ns \\
\hline
\end{tabular}

Except for HNDVI (which was affected by the altitude and not by the slope or the slope $\mathrm{x}$ altitude interaction), all vegetation indices related with chlorophyll content were also affected by the slope and the slope $\mathrm{x}$ altitude interaction, but not by the altitude alone. In contrast with the chemical composition, the orientation had a significant effect $(\mathrm{P} \leq 0.001)$ on all vegetation indices related with chlorophyll content. The orientation $\mathrm{x}$ density interaction also had a consistent, though less significant, effect $(\mathrm{P} \leq$ 0.01). In contrast with chlorophyll content indices, PRI, SIPI and NPCI (defined in Table 1) were significantly affected $(\mathrm{P} \leq 0.05)$ by the slope and its interaction with density.

Changes in leaf characteristics with altitude have been documented in several studies. Increasing altitude was related to decreasing leaf $\mathrm{N}$ content, photosynthetic pigments content, and photosynthesis rate (Zhang et al., 2005), and also to alterations in the reflectance spectra and vegetation indices which indicated lower chlorophyll content and lower photosynthetic efficiency (Richardson and Berly, 2002). Other characteristics affected were leaf cell structure and the concentrations of other pigments, like carotenes (Kofidis et al., 2003; Richardson et al., 2001; Richardson and Berlyn, 2002). However, several environmental factors change with altitude, like temperature, solar radiation (in particular UV), air humidity and evaporative demand, and probably soil fertility. In the present study, temperature and humidity were probably affected more by site orientation and slope than by altitude, while exposure to solar radiation was affected by orientation and density.

By comparing Tables 2 and 3, it can be noted that the environmental factors affecting leaf chlorophyll (essentially the altitude $\mathrm{x}$ slope and the orientation $\mathrm{x}$ density interactions) are those determining exposure to solar radiation. These factors are the same that affect vegetation indices based on green and REP bands which correlate well with the chlorophyll content. On the other hand, HNDVI index, which is known to be sensitive to internal leaf structure, contrary to SIPI, is affected by altitude, 
like C content. PRI, well correlated with light use efficiency, is mostly affected by slope, like CLA/B ratio.

Wavelengths involved in the calculation of the vegetation indices presented here have been compared with corresponding spectral bands (when available) of the main remote sensing satellites (without considering the hyperspectral ones): SPOT, Landsat, MERIS and MODIS. Index R550 is the only one that can be obtained with all the satellites, since all of them provide measurements in the green band; for example, Houborg and Boegh (2008) used SPOT green reflectance to map chlorophyll in an agricultural area in Denmark). However, the influence on pixel reflectance of illumination and soil conditions is more important with single reflectance values than when a combination of bands is used. Only MERIS offers sufficient information for calculating the other indices studied here (Clevers et al., 2002; Curran and Steele, 2005): REP and MTCI obviously, by design of the satellite bands and the index respectively, and (Chl)RI could be calculated using approximations that remain to be validated. Any of these satellites allow the calculation of PRI; however, thanks to the programmability of MERIS's default bandset, it would be possible to calculate PRI from MERIS images. A limit in the utilization of MERIS images is that they provide only medium resolution. Spectral resolution can also be important: broad spectral band sensor data commonly available ( $>$ $20 \mathrm{~nm}$ ) can be sensitive enough to discern only very broad categories of forest damage (Campbell et al., 2004; Pu et al., 2008).

Changing the measurement scale from leaf to canopy level for using satellite data implies, in addition to the leaf chlorophyll content, a measurement of the amount of vegetation. This can be done using leaf area index (LAI). The extent to which leaf chlorophyll content can be estimated from reflectance measurements at canopy and landscape scales remains uncertain as canopy reflectance is also strongly affected by other factors such as canopy architecture, chlorophyll distribution into the canopy, soil background, etc., which mask changes in canopy reflectance caused by leaf chlorophyll (Blackburn and Ferwerda, 2008; Gitelson et al., 2005; Sims and Gamon, 2002).

\section{ACKNOWLEDGEMENTS}

This work was funded by the PROMEP program of the Secretaría de Educación Pública, México and by the Coordinación de la Investigation Científica of the Universidad Michoacana de San Nicolás de Hidalgo (CIC-UMSNH). The authors wish to thank the Dirección General de Vida Silvestre (SEMARNAT-México) for the sampling permits granted to realize this work (SGPA/DGVS/00808), as well as the Monarch Butterfly Reserve for the help they offered.

\section{BIBLIOGRAPHY}

Baret F, T Fourthy (1997) Radiometric estimates of nitrogen status of leaves and canopies. In: Diagnosis of the Nitrogen Status in Crops. G Leamire (ed). Springer-Verlag. Berlin, Germany. pp:201-228.

Barnes J D, L Balaguer, E Manrique, S Elvira, A W Davison (1992) A reappraisal of the use of DMSO for the extraction and determination of chlorophylls $\mathrm{a}$ and $\mathrm{b}$ in lichens and higher plants. Env. Exp. Bot. 32:85-100.

Blackburn G A (2007) Hyperspectral remote sensing of plant pigments. J. Exp. Bot. 58:855-867.

Blackburn G A, J G Ferwerda (2008) Retreival of chlorophyll concentration from leaf reflectance spectra using wavelet analysis. Rem. Sens. Env. 112:1614-1632.

Campbell P K E, B N Rock, M E Martin, C D Neefus, J R Irons, E M Middleton, J Albrechtova (2004) Detection of initia damage in Norway spruce canopies using hyperspectral airborne data. Int. J. Rem. Sens. 25:5557-5584.

Clevers J G P W, S M de Jong, G F Epema, F van der Meer, W H Bakker, A K Skidmore, K H Scholte (2002) Derivation of the red edge index using the MERIS standard band setting. Int. J. Rem. Sens. 23:3169-3184.

Curran P J, C M Steele (2005) MERIS: the re-branding of an ocean sensor. Int. J. Rem. Sens. 26:1781-1798.

Dash J, P J Curran (2004) The MERIS terrestrial chlorophyll index. Int. J. Rem. Sens. 25:5403-5413.

Gitelson A, M N Merzlyak (2004) Non-destructive assessment of chlorophyll, carotenoid and anthocyanin content in higher plant leaves: Principles and algorithms. In: Remote Sensing for Agriculture and the Environment. S Stamatiadis J, Lynch J S, Schepers J S (eds). Peripheral Editions. Larissa, Greece. pp:7894.

Gitelson A A, A Viña, V Ciganda, D C Rundquist, T Arkebauer (2005) Remote estimation of canopy chlorophyll content in crops. Geophys. Res. Lett. 32:1-4.

Houborg R, E Boegh (2008) Mapping leaf chlorophyll and leaf area index using inverse and forward canopy reflectance modelling and SPOT reflectance data. Rem. Sens. Env. 112:186-202.

Houborg R, M Anderson, C Daughtry (2009) Utility of an imagebased canopy reflectance modelling tool for remote estimation of LAI and leaf chlorophyll content at the field scale. Rem. Sens. Env. 113:259-274.

Kofidis G, A M Bosabalidis, M Moustakas (2003) Contemporary seasonal and altitudinal variations of leaf structural features in oregano (Origanum vulgare L.). Ann. Bot. 92:635-645.

Le Maire G, C Francois, K Soudani, D Berveiller, J-Y Pontailler, N Bréda, H Gener, D Hendrik, E Dufrene (2008) Calibration and validation of hyperspectral indices for the estimation of broadleaved forest leaf chlorophyll content, leaf mass per area, leaf index and leaf canopy biomass. Rem. Sens. Env. 112:38463864.

Oppelt N, W Mauser (2004) Hyperspectral monitoring of physiological parameters of wheat during a vegetation period using AVIS data. Int. J. Rem. Sens. 25:145-159.

Peñuelas J, J A Gamón, K L Griffinand, C B Field (1993) Assessing community type, biomass, pigment composition and photosynthetic efficiency of aquatic vegetation from spectral reflectance. Rem. Sens. Env. 46:110-118.

Peñuelas J, F Baret, I Filella (1995a) Semi-empirical indices to assess carotenoids/chlorophyll a ratio from leaf spectral reflectance. Photosynthetica 31:221-230. 
Peñuelas J, I Filella, J A Gamon (1995b) Assesment of photosynthetic radiation use efficiency with spectral reflectance. New Phytol. 131:291-296.

Pinkard E A, V Patel, C Mohammed (2006) Chlorophyll and nitrogen determination for plantation-grown Eucaliptus nitens and $E$. globulus using a non-destructive meter. For. Ecol. Manage. 223:211-217.

Pu R, M Kelly, G L Anderson, P Gong (2008) Using CASI hyperspectral imagery to detect mortality and vegetation stress associated with a new hardwood forest disease. Photogram. Eng. Rem. Sens. 74:65-75.

R Development Core Team (2010) R: A Language and Environment for Statistical Computing. R Foundation for Statistical Computing, Vienna, Austria. ISBN 3-900051-07-0. Disponible en: (http://www.R-project.org).

Richardson A D, G P Berlyn, T G Gregoire (2001) Spectral reflectance of Picea Rubens (Pinaceae) and Abies balsamea (Pinaceae) needles along an elevational gradient, Mt. Moosilauke, New Hampshire, USA. Am. J. Bot. 88:667-676.
Richardson A D, G P Berlyn (2002) Spectral reflectance and photosynthetic properties of Betula papyrifera (Betulaceae) leaves along an elevational gradient on Mt. Mansfield, Vermont, USA. Am. J. Bot. 89: 88-94.

Secretaría de Medio Ambiente y Recursos Naturales, SEMARNAT (2001) Programa de Manejo de la Reserva de la Biósfera Mariposa Monarca. Comisión Nacional de Áreas Naturales Protegidas. México. 159 p.

Sims D A, J A Gamon (2002) Relationships between leaf pigment content and spectral reflectance across a wide range of species, leaf structures and developmental stages. Rem. Sens. Env. $81: 337-354$

Steele M, A Gitelson, A Rundquist (2008) A comparison of two techniques for non-destructive measurement of chlorophyll content in grapevine leaves. Agron. J. 100:779-781.

Zhang S B, Z-K Zhou, H Hu, K Xu, N Yan, S Y Li (2005) Photosynthetic performances of Quercus pannosa vary with altitude in the Hengduan Mountains, southwest China. For. Ecol. Manage. 212:291-301. 